J. Range Manage.

48:350-357 July 1995

\title{
Viewpoint: Grazing management and research now and in the next millennium
}

\author{
JOHN W. WALKER
}

The author is Range Scientist, USDA Agricultural Research Service, U.S. Sheep Experiment Station, Dubois, Ida. 83423.

\begin{abstract}
Livestock have been a key factor in the development of civilization, but what will their role be in the future and how should the science of rangeland management change to meet the challenges of the future? In this paper I look at current grazing management in the context of paradigm shifts and scientific revolution. The impact of livestock on rangelands occurs primarily because livestock selectively defoliate the available herbage rather than indiscriminately consuming herbage according to its availability. Grazing management via the use of traditional grazing systems does not appreciably affect selective foraging behavior. Trends of the future that will affect societal demands and available technologies include: 1) no lack of resources or food; 2) increased concern for environmental quality; 3) greater demand for open space values of rangelands; and 4) geometric increase in the availability of technologies from molecular biology to solve management problems. The 4 principles of grazing management i.e., 1) timing, 2) distribution, 3) kind/class of livestock, and 4) stocking rate, will not change. Stocking rate is the most important variable in grazing management. If stocking rate is not near the proper level then regardless of other grazing management practices employed objectives will not be met. The ability to determine the proper stocking rate will be hindered by the inability to determine carrying capacity as it varies over time. To change the grazing habits of the animals we must work directly on the genetics of the animal. However, the way we manipulate and manage grazing animals will improve, and our ability to monitor the impact of grazing must also improve. In addition to commodity production, livestock grazed on natural plant communities will also have to simultaneously impact these communities to provide the types of habitat demanded by society. The most important emerging technology for the management of grazing livestock will be genetic manipulation using both classical selection procedures and genetic engineering. New technologies for monitoring impact of livestock on the rangeland resource and for setting and adjusting stocking rates will also be critical. Interdisciplinary research must be encouraged to meet the future demands.
\end{abstract}

I would like to thank Marty Vavra and the members of the Research Affairs Committee, SRM I for inviting me to develop the ornginal version of this manuscript and thus chaltenging me to stretch my thinhing.

Manuscript Accepted 11 Nov. 1994.
Key Words: philosophy, history, technology, grazing systems, paradigm shift, diet selection, genetic selection

Livestock were domesticated 10,000 to 11,000 years ago in the Neolithic (New Stone Age) period (Cambell and Lasley 1969, Pearse 1971). Domestication of herbivores ranks as one of the most significant occurrences of history (Langer 1952). This event was not only responsible for the development of civilization but shaped it as well (Bronowski 1973). The wheel and the plough were invented only in societies that domesticated draught animals. Thus, in the Americas where draught animals were not domesticated the wheel and plough did not exist (Bronowski 1973). The present challenge is to predict the role of ruminant livestock in future food production systems and the role of the science of rangeland management in developing technologies for livestock production that are compatible with societal goals. The objectives of this paper are: 1) review the current state of grazing management; 2 ) review predicted trends in science and technology for this decade and the next century; and 3) predict how this will affect grazing management and research in the future. While the thoughts and predictions expressed in this paper were not arrived at lightly, no claim of their accuracy is made. If this effort does no more than stimulate critical analysis of the state of range livestock production it will have served its purpose.

In beginning this attempt to recommend future directions for range livestock production research I will begin with a few precautionary notes. Kates et al. (1990) described the management of the Harvard Forest which was established at the turn of the last century as a pioneer research and education program and an early American center for experiments with new notions of sustainable yields and multiple use in forestry. These authors (Kates et al. 1990) drew the following conclusions from the history of the management of that resource. "The very best scientist of any time may only poorly understand the fundamental processes governing nature, society, and the relationships between them; in this case, which trees are edaphic, how species composition changes, how demand for species changes, and how catastrophic surprise can occur. Our attempts to understand the current transformation of the earth and the various transformation trajectories will surely offer many examples of failure to understand process or to anticipate surprise."

In reviewing the history of range livestock research and management I will try to interpret it considering Thomas Kuhn's (1970) theories of normal science and scientific revolution. I will 
try to determine if grazing management and the theories that support it are accumulating sufficient anomalous information to warrant a paradigm shift.

In looking toward the future I will briefly review some predictions of futurists such as John Naisbitt and Eric Drexler, because the future of range livestock production and research will be directed by the social, political, and economic norms of the time. Then based on my experience and my insight into technology that should be available in the future I will paint a picture of how I believe grazing livestock will be managed in the future and what direction research should take to get us there.

\section{Normal Science and Scientific Revolution}

Kuhn's (1970) view of how science operates is that most research is conducted within the context of normal science. Scientists are trained to be highly competent puzzle-solvers who will be content to work within the agreed framework of rules and theories i.e., the current paradigm, governing normal science. Because new theories demand large-scale paradigm destruction and major shifts in the problems and techniques of normal science, the emergence of new theories are generally preceded by a period of pronounced professional insecurity. As one might expect, insecurity is generated by the persistent failure of the puzzles of normal science to come out as they should. Failure of existing rules is the prelude to a search for new ones (Kuhn 1970, p. 67-68). The transfer of allegiance from paradigm to paradigm is a conversion experience that cannot be forced. Lifelong resistance, particularly from those whose productive careers have committed them to an older tradition of normal science, is not a violation of scientific standards but an index to the nature of scientific research itself (Kuhn 1970, p. 151). While there is much debate among philosophers of science over Kuhn's thesis (see Lakatos and Musgrave 1970), many prominent practitioners of science seem to support Kuhn's view of how science is conducted. Albert Einstein stated "It is the theory which decides what we can observe." This indicates there are no neutral observations and all data are theory laden. Nobel physicist, Max Planck said "New theories rarely get accepted by rational persuasion of the opponents-one simply has to wait until the opponents die out."

As I review the current paradigm of grazing management and range livestock research it will be in the context of trying to discover if our profession is changing paradigms; or if we can go into the future by solving increasingly complex and technical puzzles derived from the current paradigm. I recognize this attempt is limited in that it pursues a reductionist left brain linear solution to the questions. This is a result of personal limitation rather than skepticism that right brain emergent systems with chaotic properties may ultimately provide a more satisfactory solution (Gleick 1987, Waldrop 1992).

\section{Paradigm Shifts and Grazing Management}

Grazing management is important because this is where theory is put into practice. Principles of grazing management and grazing systems should embody our knowledge of animal requirements, foraging behavior, and plant ecology into a unified system to obtain management goals. Therefore, the degree to which a prescribed grazing management practice meets management objectives should reflect the level of understanding of the basic principles of grazing management.

Proper grazing management involves much more than complex systems of rotation, but for this paper I will address the issue primarily in terms of rotational grazing because this seems to be the cornerstone of much government agency policy (Malechek 1984). Sanford's (1983) statement about western-trained grazers and scientist becoming "obsessed with implementing grazing rotations" (emphasis added) supports the view that rotational grazing systems are considered the cornerstone of grazing management. Although biological processes affected by the principles of grazing systems may not be agreed upon by all practitioners I believe it is safe to conclude there are 2 presumed benefits to rotational grazing: 1) it affects patterns of defoliation, and 2) plant community composition improves with planned rest. The second issue is outside the scope of this paper but paradigms of species constant climax and linear successional change are being overthrown and a new paradigm of nonequilibrium theory is replacing it (Walker 1988 a \& 1988b, Westoby et al. 1989, Friedel 1991, Laycock 1991, George et al. 1992, Johnson and Mayeux 1992, National Research Council 1994, West et al. 1994). In simple rotation systems defoliation is affected temporally by controlling the presence or absence of livestock in a pasture. However, in intensive rotation systems an initial hypothesis was that concentration of animals would decrease selective grazing (Malechek and Dwyer 1983, Gammon 1984, Kothmann 1984). This hypothesis has been rejected in many studies (Gammon and Roberts 1978a; 1988b, Taylor et. al 1980, Long et al. 1982, Walker et al. 1988a; 1988b; 1988 Taylor et al. 1993).

Humans have unsuccessfully attempted to manipulate patterns of defoliation by livestock since antiquity. Sheep herding sometimes called the "second oldest profession" represents the long standing attempt by man to control the grazing behavior of livestock for his benefit. Herding is the most intensive form of grazing management known. Some of the worst cases of overgrazing are in areas of the world where herding has always been the predominant form of grazing management (e.g., sub-Saharan Africa, Middle East; Pearce 1971). One might assume the problem of controlling patterns of defoliation is related to insufficient knowledge of principles of grazing management. However, the basic principles of the most intensive grazing systems were recorded long ago (see Anderson 1777). Furthermore, it is naive to believe that cultures that have lived in a close symbiotic relationship with their livestock for generations would not have developed a keen understanding of the principles of grazing management (Mahoney 1966, Pearse 1971). During the past 20 years there has been a strong effort to engineer grazing systems that will increase carrying capacity and livestock performance. The basic principle of these grazing systems was to control the frequency and intensity of defoliation of individual plants (Heitschmidt and Walker 1983). However, Barnes (1982) stated "The weight of evidence, therefore, is that accurate control of defoliation pattems in savanna by means of rotational grazing is an unattainable ideal" (emphasis added). This suggests that while controlling defoliation (i.e., diet selection of the grazing animal) was the objective, grazing systems do not substantially affect this process in most cases. The inability to control selective grazing is typically ignored however when the management of rangelands is planned (Malechek 1984). 
Obtaining the appropriate stocking rate is the most important principle of grazing management (Holechek et al. 1989, Heady and Child 1994). Carrying capacity is the maximum stocking rate possible which is consistent with maintaining or improving vegetation or related resources (Society for Range Management 1989). Thus obtaining the appropriate stocking rate is dependent upon estimating the carrying capacity of the resource. Carrying capacity depends on both the production potential of the resource and the management practices in place. For instance fencing that improves livestock distribution (Hart et al. 1993) or multi-species grazing (Cook 1954) that improves uniformity of defoliation can increase carrying capacity. Management inputs will not ameliorate the effect of over stocking because by definition over stocking implies forage demand exceeds carrying capacity regardless of the effect of other management options on carrying capacity. If stocking rate exceeds carrying capacity it generally results in a change in plant community composition to one that is less productive or of lower value as livestock forage. This occurs because selective grazing places preferred plants at a competitive disadvantage to other plants in the community (Briske 1991).

Hardin (1968) argues that exceeding the carrying capacity is a social problem and cannot be remedied by new technology. Overgrazing occurs when animals are owned by individuals but grazing land is held in common (i.e., the tragedy of the commons). This occurs because the benefit to the individual of increasing animals numbers is greater than the cost that is shared by all individuals grazing the common. The solution to this problem according to Hardin is the privatization of agricultural land. Unfortunately, there is ample evidence that this does not eliminate overgrazing. There are 2 reasons for this, one is social and the other is technological. The social problem arises, in part, because the future is also a common. This allows individuals to receive full benefit from over stocking while the cost is shared with succeeding generations. This is particularly true when the present tenants lack a long term (i.e., multiple generation) commitment to the resource. The need for a long term commitment is reflected in a proverb attributed to many cultures "Treat the earth well. It was not given to you by your parents. It is lent to you by your children."

The technological problem associated with overgrazing is the inability to accurately determine carrying capacity (Holechek 1988, Vallentine 1990, Walker 1993). This is caused by the tremendous spatial diversity of rangelands compounded by climatic variation and the impact of management practices. One consequence of this variability is that proper stocking rate varies, not only over time and space, but also as a function of managements goals related to risk and catastrophe. Higher stocking rates result in greater economic returns, but they also result in a higher probability of encountering catastrophic losses (Conner 1991). Thus a great need for proper grazing management is monitoring and modelling techniques that will accurately determine the relationship between level of stocking and carrying capacity in real time.

The challenge facing grazing managers is ameliorating the antagonistic relationship between increasing the efficiency of nutrient harvest by livestock and the efficiency of energy capture by primary producers (Briske and Heitschmidt 1991). This will not be done within the paradigm of designing a better grazing system but will require a new perspective for this age old problem of manipulating diet selection.

\section{Foraging Behavior}

Selective grazing is demonstrated in all herbivores from insects to livestock. In this paper diet selection refers to the hierarchical model that considers all processes from landscape selection to bite selection as part of the foraging process (Senft et al. 1987). Diet selection is a key process affecting both the grazing animal's nutrient status and successional processes in plant communities. By preferring some plants and avoiding others, ruminants have a profound effect on the competitive interactions of plants and consequently on the structure and function of ecosystems (Archer and Smeins 1991, Belsky 1992). Much of the adverse environmental impact of grazing livestock on plant communities is directly attributable to what and where they graze. Generally it is thought that animals selectively graze to acquire particular nutrients and avoid other food components (e.g., toxins). This is based on the idea that the forager would not acquire sufficient amounts of nutrients for survival or would acquire excess amounts of detrimental components if the forager simply selected foods at random (Belovsky and Schmitz 1991, Rogers and Blundell 1991).

Relative to its impact on plant community structure, diet selection is by far the most important aspect of foraging behavior. Initial studies on diet selection were primarily descriptive and the emphasis was on differentiating preference (the observed diet selection in the current environment) from palatability (the combination of plant characteristics that stimulates animals to prefer a forage; Heady 1964). As implied by the separation of palatability as a plant characteristic from preference as the interaction of the animal with its grazing environment (i.e., plant-animal interface) certain physical properties of plants were thought to elicit preference or avoidance as an innate animal response.

Diet selection can be grouped into 2 categories namely, innate or learned. As with many dichotomies the one between innate and learned behavior is not mutually exclusive, e.g., the ability to learn is innate. However, these categories provide a framework for discussing the processes affecting diet selection. Identifying diet selection processes that are under innate verses environmental control suggests whether efforts to affect the process should be directed at the genetic or the environmental influences on an organism.

Learning as a mechanism that explains foraging behavior is flexible and adaptive to most conceivable foraging challenges encountered by ruminants (Provenza and Balph 1990). If learning is the primary causal mechanism controlling diet selection, it might appear to have the added advantage of being readily manipulated, just as dogs can learn to do many tricks. The basic tenet of the learning model is the frequency of a behavior increases if it is followed by positive consequences and the frequency decreases if it is followed by a negative consequence. Furthermore, in nature, learning is adaptive, i.e., it contributes to the fitness of the individual.

Within their sensory capabilities to cognitively recognize a forage plant and detect its contribution to their fitness, animals can presumably make appropriate diet selection choices. Failure of animals to select an appropriate diet (e.g., consumption of poisonous plants) is thought to occur when the range of food items exceeds the physiological and sensory capabilities of the animal, not the inadequacy of the learning model (Provenza et al. 1992). Manipulation of diet selection by affecting the learning process is apparently limited to enhancing the rate of learning that would 
nccur by trial and error learning. This is because any behavior that is modified by altering the cue consequence feedback loop with diet training should be extinguished when the cognitive cues of the food item no longer accurately predict its postingestive consequence. This occurs because of an active process of learning known as extinction. Learning is a mechanism that relates cognitive properties of a food item to its post-ingestive consequences. However, learning does not affect these consequences. Therefore, in the long run, animals can only be taught to prefer plants that inherently provide positive consequences for them or avoid plants that inherently provide negative consequences.

Long-term manipulation of diet selection by livestock will depend upon genetic manipulation of the animals or their microbial symbionts. This is already done when the dietary habits of the livestock species is matched to the characteristic of the rangeland resource. Unfortunately, this factor is only rarely considered when grazing management decisions are made. Although it is recognized that individual variation (i.e., the basis for genetic selection) in diet selection exist (Dove 1935, Marten 1978. Arnold and Dudzinski 1978. Marinier and Alexander 1991), I am aware of no research that attempted to directly select for diet preference in livestock. The potential success for selection as a tool to modify foraging behavior to meet human needs is demonstrated in domestic dogs (Fox 1978). Stock dogs have been selected to bite either the head or heels of livestock (Lithgow 1987). This could be considered analogous to breeds of cattle that graze either leaves or stems. Furthermore, Marinier and Alexander (1991) have shown foraging behavior in horses is related to genetic lineage and different lines appear more prone to plant poisoning. In fruitflies (Drosophila melanogaster), preference for high protein or high energy diets was affected by genetic selection (Wallin 1988). Foraging behavior has not been directly selected for in the past because an adequate screening procedure for determining diet selection on large numbers of individuals has not been available.

I have discussed 2 major problems in the management of range livestock, namely overgrazing and the inability to influence diet selection. Both problems were related in part to inadequate technology. Range livestock research has been hindered by inadequate technology since its inception.

\section{The Future}

Before I address the topic of range livestock production and research in the 21 st century it is important to develop an idea of just what the 21 st century will be like socially, politically, culturally, and economically. This is important because we do not produce commodities or information in a vacuum. The value of the products of rangelands and range research will only be as great as the demand for the product. Therefore, it behooves the profession and producers to do some market research to determine the demands of consumers in the future. This is particularly important with the long production cycles of red meat and new research ideas.

Naisbitt and Aburdene (1990) predict an economic boom in the 1990's. "The global boom of the 1990's will be free of the limits on growth we have known in the past. There will be an abundance of natural resources throughout the 1990's from agricultural products and raw materials to oil. Everything that comes out of the ground will be in oversupply for the balance of this century and probably much longer. We will need fewer raw materials, as we have been moving away from material-intensive products for decades. A prototypical example of the shift away from the material intensive is fiber-optic cable. Just seventy pounds of fiberoptic cable can transmit as many messages as 1 ton of copper wire. Equally important, those 70 pounds of fiber-optic cable require less than $5 \%$ of the energy needed to produce 1 ton of copper wire. There will be no energy crisis to impede the 1990's global boom. Each year since 1979 the United States has used less energy than the year before."

The only food problems today are distribution and political problems. Brian Walker (1988) stated "we need to question the long-term objective of rangeland production. Is it simply to produce more meat or wool? If so, who wants it? The projected world food crisis seems to get further away each year, as more and more countries achieve self sufficiency." The major agriculture production problem in the U.S. today is competition for world export markets. Since the early 1970's the United State's share of world agricultural exports have fallen from $29 \%$ to $20 \%$, while the European Common Market's share has risen from 13 to $19 \%$ (Kilman 1992). Avery (1992) stated "The danger is that our farm industry could get left on the sidelines even as the world triples its farm demand due to a larger and richer population."

Looking past the year 2000, Drexler et al. (1991) state that nanotechnology will allow "the human race to feed itself with ordinary, naturally grown, pesticide-free foods while returning more than $90 \%$ of today's agricultural lands to wilds." If these trends continue, it means if agricultural research is to maintain its credibility it cannot use gloom and doom predictions that have been in use since Malthus (1778) to justify future research.

As part of this economic boom Naisbitt and Aburdene (1990) predict a new attentiveness to the environment. "The world's preoccupation with defense and the cold war, which is receding, is being replaced by concerns about the destruction of our natural environment, now our most important common problem." The wealth of nature has come to include nature as a value in itself (Rolston 1989). Consequently, greater wealth has begun to mean cleaner, greener wealth (Drexler et al. 1991). Range scientists and managers can take pride in a tradition of viewing range management as a sustainable process that must be conducted within ecological constraints of fragile environments. Considering the importance the public will continue to put on environmental quality, it is critical that maintaining environmental quality is the cornerstone of future research. This does not imply that range managers can ignore the importance of commodity production, but that commodity production must be considered as only one of the products of rangelands.

Naisbitt and Aburdene (1990) predict a new electronic heartland. "Linked by telephones, fax machines, Federal Express, and computers, a new breed of information worker is reorganizing the landscape of America. Free to live almost anywhere, more and more individuals are deciding to live in small cities and towns and rural areas. A new electronic heartland is spreading throughout developed countries around the globe, especially in the United States. Quality-of-life rural areas are as technologically linked to urban centers as are other cities. This megatrend of the next millennium is laying the ground work for the decline of cities." In agreement with Naisbitt and Aburdene (1990), Swasy (1994) stated: "Today's white-collar boom towns were yester- 
day's cow pastures." Since most natural resources managers and agriculturalists were lead to their vocation at least in part because of life style considerations this should be no surprise. In the future this will only mean greater demands on rangelands.

The other prediction pertinent to the topic of this paper is the 1990's will be the age of biology. We will have the ability to create organisms by genetic engineering to produce whatever product society demands (Naisbitt and Aburdene 1990). Scientists involved in genetic engineering are echoing this prediction. Boyd and Samid (1993) state: "The amazing pace of discovery within the field of molecular biology has expanded the understanding of as well as the potential for genetic engineering in laboratory and domestic animals. The future of the planet Earth and the species that inhabit it can be significantly affected by these technologies. The use of transgenic animals is limited only in the human imagination."

\section{Range Livestock Production and Research in the Future}

The first question that must be answered concerning range livestock production in the future is where and how these commodities will be produced. In doing this I will assume that at least until the end of my career that ruminant livestock will be produced using the basic principles of nutrition and husbandry that have been used traditionally. This is in contrast to the increased development of animal factories predicted by some. But, technological innovations may influence the location and resources used in production. For instance, in 1960, $79 \%$ of the calf crop was fed concentrates, and by the early 1970's this proportion had risen to 95\% (Reimund et al. 1981). This affected the geographic area where cattle were finished and slaughtered. Joyce (1989) predicted that by the year 2040 , demand for red meat would increase $56 \%$ above 1985 levels. This will result in an increased forage demand of $54 \%$. Most of this additional forage demand will be supplied by production from deeded nonirrigated range and pasture land and will require an increased production of $71 \%$ to meet the demand. Joyce (1989) suggest that 150 existing and potential technologies will be available by the year 2000 to increase forage production. However, capital requirements for these new technologies will probably cause them to be used primarily on pasture and forage crops. Thus, the greatest potential for increased production will presumably be on improved pasture and forage crops rather than rangelands.

The total cost of using extensive rangelands for livestock production is often greater than it appears and rangeland forages may not be competitive with forage from improved pasture (Glimp 1991). In Oklahoma beef production per unit land area was increased 5 fold on improved pasture compared to rangeland (Glimp 1991). Joyce (1989) predicted a reduction in the number of livestock operations that depend on public land grazing. Technologically driven, economic increases in forage production and utilization systems on irrigated lands or improved pasture land in humid regions could further shift red meat production from rangelands. However, this does not imply that rangelands will be an insignificant resource for livestock production. The fact remains that rangelands occupy about $50 \%$ of the land area and grazing is the only use of rangelands that converts solar energy captured on rangelands to commodities, useful to mankind. We simply cannot ignore such a vast resource. Though rangelands will continue to be important for livestock production, they will not be the growth areas in the next century.

Shifts in the types of lands where forage for livestock production will likely occur and predicted increases in demands for recreation and nonconsumptive use of rangelands will provide the impetus and direction for the future of range livestock research. Future research on grazing animal ecology should be directed toward manipulating diet selection and foraging efficiency but the objective of new technologies will depend upon the type of land upon which new technologies arc applied. If red meat production is concentrated on improved pastures the obvious objective of the new technology will be increasing economic returns. This will require technologies that improve the efficiency of forage harvest and conversion to livestock products. Potential technologies will include manipulation of rumen micro flora and fauna to digest forages more efficiently and selection of animals with high biological efficiency for converting forages to livestock products (Robinson and McEvoy 1993). Efforts are currently underway to develop grazing strategies that will increase the efficiency of harvest of highly productive forages (Volesky 1990).

On rangelands the objective of grazing management will place greater emphasis on manipulation of plant communities. However, the production goal will continue to be maximization of long term economic return. For as Ainesworth (1989) stated "The only sustainable agriculture is profitable agriculture." Commodity production will still be important but all classes of livestock will be considered dual product animals i.e., commodity production and vegetation manipulation. just as sheep are currently thought of as dual purpose animals. The challenge for researchers and extension personnel will be making an orderly transition from single objective livestock production to dual objective livestock production.

Society has many environmental concerns that rangeland scientists can address. These concerns include global climate change, biodiversity, and sustainable agricultural production systems. As scientists we are more comfortable developing theories and hypothesis than recommending solutions to agricultural and environmental problems. One reason curriculums in conservation biology and environmental restoration are emerging is because the old disciplines of range science, wildlife science, and forestry did not rise to meet these challenges. Now and in the future natural resource scientists are going to be involved in developing land use policy, and management plans will be evaluated in the legal courts rather than the peer reviewed literature (Murphy and Noon 1991). As Barker (1994) wrote regarding forest management in the Pacific Northwest: "While hundreds of scientists can debate whether Clinton's plan meets his promise to use good science, only Dwyer (U.S. District Judge) will decide whether it meets the law."

\section{Possible Scenarios for Grazing Management in the Future}

How will grazing be conducted on extensive rangelands in the future? Successful grazing management will be based on the ability to accomplish 3 objectives: 1) control what animals graze, 2) control where they graze, and 3) monitor the impact on both the environment and the animal. The following is one possible scenario.

The idea of livestock as large generalist herbivores may be a thing of the past. Rather livestock will be genetically manipulated to select diets that are most appropriate for the environment and 
management goals of the grazier. Genetic manipulation will come in several forms. It may be provided using classical selection and animal breeding techniques or it may result from inserting a specific gene into a breed producing an enzyme required to break down a specific phytotoxin found in the environment. The case of tansy ragwort (Senecio jacobaea L.) is an excellent candidate for the latter approach. Sheep already have enzymatic systems that allow them to detoxify this plant (Wachenheim et al. 1992). If the genes responsible for this system were identified and inserted into cattle, they could turn this poisonous plant into a source of nutrients.

Potential for genetic modifications are closer than many realize. For example 38 gene constructs have been integrated into the genomes of farm animals since the first transgenic modification of livestock was reported in 1985 (Pursel and Rexroad 1993). In addition to modifying the animal, microbial symbionts may also be genetically manipulated. Ruminant livestock will be inoculated with a suite of microorganisms tailored for the animal's foraging environment. Among other things, this will include rumen microorganisms that can digest lignin (Robinson and McEvoy 1993) which will prove to be of great benefit to forage breeders who must balance the antagonistic relationship between high production and high levels of structural carbohydrates. Dosing ruminants with DHP-degrading bacteria to ameliorate toxicity of leucaena (Leucaena leucopephela Lam.) is already a common practice (Jones and Megarrity 1986, Pratchett et al. 1991). If environmental concerns related to livestock grazing are of greater importance than increased efficiency of production then we should work with genetic engineers to encode traits we believe to be important into livestock. Control of livestock distribution will be accomplished electronically without the use of fences. Prototypes have already been designed and are commercially available (Quigley et al. 1990, Rose 1991). I envision systems that use implantable electric stimulators (Rose 1991) linked to geographic positioning systems to precisely control the location of grazing animals. Furthermore, composition and utilization of range vegetation will be accurately monitored by remote sensing. This information will be used by a systems model to determine the location these electronically controlled and genetically engineered animals will graze.

Education and research will be part of the solution to the problem of large scale conversion to dual objective grazing management strategies. While it is generally well recognized that grazing livestock can adversely impact native plant communities and result in range retrogression it is less commonly acknowledged that the same process, i.e., selective grazing can positively impact plant communities. Research is necessary to enhance control of diet selection and producers need to be educated in the potential value of selective grazing so they can manage and charge accordingly for this capability. Plantation grazing to remove competing herbaceous vegetation and enhance timber production is an example of the positive effect of selective grazing. In other situations the value of livestock grazing is not yet fully appreciated. For instance, although grazing with sheep and goats can reduce amount of leafy spurge (Euphorbia esula L.) by over $90 \%$ in 4 years (Johnson and Peake 1960), this method of leafy spurge control is only recommended for "worst case" situations that are beyond the economic use of herbicides (Fay 1989). It seems counter productive to recommend the use of herbicides to control undesirable plants at a cost that may exceed the value of the land when livestock can be used to accomplish the same goal at a net economic return.

\section{Research Strategies}

While a vision of the future is important (i.e., you have to know where you are going if you ever hope to get there) the vision described above is only one possibility and many others could be proposed that would be equally valid. For scientists the more important question is how will research in natural resource ecology and management be conducted in the future. This is the paradigm with the greatest potential for real change in the future. The greatest need in rangeland research today is the development of integrated research teams that concentrate on solving management problems. In the past when scientists have called for an upgrading of the quality of science they have suggested a more rigorous application of the scientific method. Following articles by Platt (1964) and Romesburg (1981) a plea for greater use of deductive logic and the design of experiments based on falsifiable hypotheses was heard in the academic community. Following Hurlbert's (1984) paper on pseudoreplication, scientists learned a new word for an old habit and the standard for publication in scientific journals was raised. Without detracting from the important contribution these papers made to improving the quality of rangeland and other natural resource sciences, in Kuhn's philosophy on scientific revolution and the conduct of normal science, these seminal papers represent only very nice jobs of putting fancy pieces into the old puzzles. Furthermore, I believe they received such wide spread attention and focus by the academic community because they allowed us to clean up our act without making the difficult changes that will be necessary to provide for societal need in the future.

Drexler et al. (1991) offer insight into the problem with current natural resources research programs. "In academic science, interdisciplinary work is productive and praised, but is relatively rare. Scientists don't need to cooperate to have their results fit together: they are all describing different parts of the same thingNature-so in the long run, their results tend to come together into a single picture. Engineering, however, is different. Because it is more creative (it actually creates complex things), it demands more attention to teamwork. If the finished parts are going to work together, they must be developed by groups that share a common picture of what each part must accomplish. They will either learn to think like engineers and work in teams, or they will be eclipsed by colleagues who do." Stuth et al. (1990 and 1991) show the benefits that can accrue to natural resource management when the goal of effective interdisciplinary research is achieved.

The reason there is little management oriented interdisciplinary rangeland research is related to 2 interrelated principles enumerated previously. The first is that frequency of a behavior increases if it is followed by positive consequences and frequency decreases if it is followed by negative consequences. The second principle is related to Maslow's (1954) hierarchy of needs and how they relate to effective rewards. Research is a learned behavior and the lack of quality interdisciplinary research reflects a lack of meaningful rewards associated with this activity. This does not deny the existence in academic institutions of recognition for team research; however, it does suggest interdisciplinary research awards are either too few or ineffective. Furthermore, among the 
many awards sponsored by the Society for Range Management there are none for team research. The most prominent needs of scientists are esteem and self-actualization and relevant rewards will fulfill these needs. Unfortunately, these needs must be met on an individual basis and by giving acknowledgement to a team the rewards are diluted relative to a colleague that receives an individual accomplishment reward, even though the effort required to work successfully on a productive team may be much greater.

\section{Conclusion}

Stocking rate is still the number one problem of grazing management and our ability to overcome this problem will in part be hindered by ability to determine proper carrying capacity. If we want to change the grazing habits of the animals we must work directly on the genetics of the animal. The 4 principles of grazing management i.e., : 1) timing, 2) distribution, 3) kind/class of livestock, and 4) stocking rate will not change. However, the way we manipulate and manage them will, and our ability to monitor the impact of grazing must also increase.

I will end this essay where it began, with a quotation from Kates et al. (1990). "Many of one generation's great fears are remembered by the next generation, if they are remembered at all, as quaint curiosities.... Predictions are not falsified only because the concerns were ill-founded or the hypothesized relationships were wrong. On the contrary, the gloomiest of forecasts may not be realized because society takes them seriously and acts upon them." Thus if our successors are challenged with a different set of problems than we face today it may indicate the problems were successfully solved.

\section{Literature Cited}

Ainesworth, Earl. 1989. LISA men have called you. Farm J. 113:I.

Anderson, James. 1777. Essays Relating to Agriculture and Rural Affairs. 2nd edition. Edinburgh, U.K.

Archer, Steve and F. E. Smeins. 1991. Ecosystem-level processes. p. 109-140. In R.K. Heitschmidt, and J.W. Stuth (eds.) Grazing management an ecological perspective. Timber Press Inc., Portland, Ore.

Arnold, G.W., and M.L. Dudzinski. 1978. Ethology of free-ranging domestic animals, Elsevier, New York, N.Y.

Avery, D.T. 1992. Farmers face their biggest test ever. Wall Street J. 127:A19

Barker, R. 1994. Clinton's plan for timber sets best course. Idaho Falls Post Register. 63:(117): $\mathrm{Cl}$

Barnes, D.L. 1982. Management strategies for the utilization of southem African savanna. p. 626-656. In: Huntley, B.J. and B.H. Walker (eds.) Ecology of tropical savannas, Ecol. Studies 42, Springer-Verlag, Berlin, Germany.

Belovsky, G.E. and O.J. Schmitz. 1991. Mammalian herbivore optimal foraging and the role of plant defenses. p. 1-28. $\mathrm{m}$ : Palo, R.T. and C.T. Robbins (eds). Plant defenses against mammalian herbivory. CRC Press. Inc., Boca Raton, Fla.

Belsky, J.A. 1992. Effects of grazing, competition, disturbance and fire on species composition and diversity in grassland communities. J. Veg Sci. 3:187-200.

Boyd, A.L. and D. Samid. 1993. Review: molecular biology of transgenic animals. J. Animal Sci. Suppl. 3, 71:1-9.

Briske, D.D. 1991. Developmental morphology and physiology of grasses. p. 85-108. In R.K. Heitschmidt, and J.W. Stuth (eds.) Grazing management an ecological perspective. Timber Press Inc., Portland, Ore.
Briske, D.D., and R.K. Heitschmidt. 1991. An ecological perspective. p. 11-26. In R.K. Heitschmidt, and J.W. Stuth (eds.) Grazing management an ecological perspective. Timber Press Inc., Portland, Ore.

Bronowski, J. 1973. The ascent of man. Little, Brown and Co., Boston. $448 \mathrm{pp}$.

Campbell, J.R. and J.F. Lasley. 1969. The science of animals that serve mankind. McGraw-Hill, Inc., New York, N.Y.

Conner, J.R. 1991. Social and economic influences on grazing management. p. 191-199 In R.K. Heitschmidt, and J.W. Stuth (eds.) Grazing management an ecological perspective. Timber Press Inc., Portland. Ore.

Cook, C.W. 1954. Common use of summer range by sheep and cattle. J. Range Manage. 7:10-13.

Dove, F.W. 1935. A study of individuality in the nutritive instincts and of the causes and effects of variations in the selection of food. Amer. Natur. 69:469-544.

Drexler, K.E., C. Peterson, and G. Pergait. 1991. Unbounding the future the nanotechnology revolution. William Morrow and Company, Inc., New York, N.Y.

Fay, P.K. 1989. Goats as an alternative to leafy spurge control. $I n:$ Ben F. Roche, Jr. and Cindy Talbot Roche (eds.) Range Weeds Revisited Symposium Proceedings. Spokane, Wash.

Fox, M.L. 1978. The dog, its domestication and behavior. Garland STPM Press. New York, N.Y.

Friedel, M.H. 1991. Range condition assessment and the concept of thres-holds: A vicwpoint. J. Range Manage. 44:422-433.

Gammon, D.M. 1984. An appraisal of short duration grazing as a method of veld management. Zimb. Agr. J. 81:59-60.

Gammon, D.M. and Roberts, B.R. 1978a. Patterns of defoliation during continuous and rotational grazing of the Matopos Sandveld of Rhodesia. 1. Selectivity of grazing. Rhod. J. Agr. Res. 16:117-131.

Gammon, D.M., and Roberts, B.R. 1978b. Patterns of defoliation during continuous and rotational grazing of the Matopos Sandveld of Rhodesia. 3. Frequency of defoliation. Rhod. J. Agr. Res. 16:147-164.

George, M.R., J.R. Brown, and W.J. Clawson. 1992. Application of nonequilibrium ecology to management of mediterranean grasslands. J. Range Manage. 45:436-440.

Gleick, J. 1987. Chaos making a new science. Penguin Books, New York, N.Y.

Glimp, H.A. 1991. Can we produce lambs for $\$ .40 / \mathrm{lb}$ ? Proc. Sheep Forage Production Systems Symp. Amer. Sheep Industry, Denver, Colo.

Hardin, G. 1968. The tragedy of the commons. Sci. 162:1243-1248.

Hart, R.H., J. Bissio, M.J. Samuel, and R.W. Waggoner Jr. 1993. Grazing systems, pasture size, and cattle grazing behavior, distribution and gains. J. Range Manage. 46:81-87.

Heady, H.F. 1964. Palatability of herbage and animal preference. J. Range Manage. 17:76-82.

Heady, H.F. and R.D. Child. 1994. Rangeland ecology and management. Westview Press, Boulder, Colo.

Heitschmidt, R.K. and J.W. Walker. 1983. Short duration grazing and the Savory Grazing Method in perspective. Rangelands 5:47-150.

Holechek, J.L. 1988. An approach for setting the stocking rate. Rangelands 10:10-14.

Holechek, J.L., R.D. Pieper, and C.H. Herbel. 1989. Range management principles and practices. Regents/Prentice Hall. Englewood Cliffs, N.J.

Hurlbert, S.H. 1984. Pseudoreplication and the design of ecological field experiments. Ecol. Mono. 54:187-211.

Johnson, H.B., and H.S. Mayeux. 1992. Viewpoint: A view on species additions and deletions and the balance of nature. J. Range Manage. 45:322-333.

Johnson, A., and R.W. Peake. 1960. Effect of selective grazing by sheep on the control of leafy spurge (Euphorbia esula L.). J. Range Manage. 13:192-195.

Jones, R.J., and R.G. Megarrity. 1986. Successful transfer of DHPdegrading bacteria from Hawaiian goats to Australian ruminants to overcome the toxicity of leucaena. Austr. Vet. J. 63:259-262.

Joyce, L.A. 1989. An analysis of the range forage situation in the United States: 1989-2040. Gen. Tech. Rep. RM-180. USDA, For Serv. Rocky Mnt. For. and Range Exp. Sta., Fort Collins, Colo. 
Kates, R.W., B.L. Turner II, and W.C. Clark. 1990. The great transformation. p. 1-18. In Turner, B.L., Il, W.C. Clark, R.W. Kates, J.F. Richards, J.T. Mathews, and W.B. Meyer (eds.) The earth as transformed by human action: Global and regional changes in the biosphere over the past 300 years. Cambridge University Press. Victoria. Aust.

Kilman, S. 1992. Amber waves U.S. is steadily losing share of world trade in grain and soybauns. Wall Street J. 127(10):A1,A12.

Kothmann, M.M. 1984. Concepts and principles underlying grazing systems: A discussant paper. p. 903-916. In: NAS-NRC. Committee on Developing Strategies for Rangeland Management. Westview Press, Boulder. Colo.

Kuhn T.S. 1970. The structure of scientific revolutions. Second Edition, Enlarged. The University of Chicago Press. Chicago, Ill.

Lakatos, I. and A. Musgrave (eds.) 1970. Criticism and the growth of knowledge. Cambridge University Press. Cambridge, U.K.

Langer, W.L. (ed.) 1952. An encyclopedia of world history. Houghton Mifllin Co., New York.

Laycock, W.A. 1991. Stable states and thresholds of range condition on North American rangelands: A viewpoint. J. Range Manage. 44:427-433.

Lithgow S. 1987. Training and working dogs for quiet confident control of stock. Univ. Queensland Press, St. Lucia, Queensland, Aust.

Long, R.E., Price, D., Pieper, R.D., Donart, G.B. and Wallace, J.D. 1982. Comparison of cattle diets under contunuous and short duration grazing. Proc. Westem Sec. Amer. Soc. Anim. Scr. 33-268-271.

Mahoney, F. 1966. Range management in the Somali Republic. p. 155-164. In A.H. Niehoff (ed.). A Casebook of social change, Aldine, Chicago. III.

Malechek, J.C. 1984. Impacts of grazing intensity and specialized grazing systems on livestock response. p. 1129-1158. In: Natl. Res. Council/Natl. Acad. Sci. Developing strategies for rangeland management. Westview Press, Boulder, Colo.

Malechek, J.C. and D.D. Duyer, 1983. Short-duration grazing doubles your livestock? Utah Sei. 4t:32-37.

Maltus, T.R. 1778. An Essay on the Principle of Population. Johnson Press, London U.K.

Marinier, S.L. and A.J. Alexander. 1991. Selective grazing behavior in horses: development of methodology and preliminary use of test to measure individual grazing ability. Appl. Anım. Beh. Sci. 30:203-221.

Marten, G.C. 1978. The animal-plunt complex in forage palatability phenomena. J. Anim. Sei. 46:1470-1477.

Maslow, A.H. 1954. Motivation and Personality. Harper and Row, New York, N.Y.

Robinson, J.J., and T.G. MIcEvoy. 1993. Biotechnology-the possibilities. Anim. Prod. 57:335-352.

Murphy, D.D., and B.D. Noon. 1991. Coping with uncertainty in wildlife biology. J. Wildl. Manage. 55:773-782.

Naisbitt, J., and P. Aburdene. 1990. Megatrends 2000 ten new directions for the $1990^{\circ}$ s. William Morrow and Company. Inc.. New York. N.Y.

National Research Council. 1994. Rangeland Health: New Methods to Classify. Inventory, and Monitor Rangelands. National Academy Press. Washington, D.C.

Pearse, C.K., 1971. Grazing in the middle east: past, present and future. J. Range Manage. 24:13-16.

Platt, J.R. 1964. Strong inference. Sci. 146-347-352.

Pratchett, D., R.J. Jones, and F.X. Syrch. 1991. Use of DHP-degrading rumen bacterid to overeome toxieity in cattle grazing irrigated leucaena pasture. Trop. Grassl. 25:268-274.

Provenza F.D., and D.F. Balph. 1990. Applicability of five diet-selection models to various foraging challenges ruminants encounter. p. 423-459. In: R.N. Hughes (ed.), Behavional mechanism of food selection. NATO ASI Series G: Ecolo. Sci.. Vol. 20. Springer-Verlag. Now York, N.Y.

Provenza, F.E., J.A. Pfister, and C.D. Cheney. 1992. Mechanisms of learning in diet selection with reference to phytotoxicosis in herbivores. J. Range Manage. 45:36-45.

Pursel, V.G., and C.E. Rexroad, Jr. 1993. Status of research with transgenic furm animals. J. Anim. Sci. Suppl. 3. 71:10-19

Quigley, T.M., H.R. Sanderson, A.R. Tiedemann, and M.L. Mcinnis. 1991. Livestack control with electrical and dudio stimulation. Rangelands 12:152-155.

Reimund, D.A., J.R. Martin and C.V. Moore. 1981. Structural change in agriculture: the experience for broilers. fed cattle. and processing vegetables. Tech. Bull. No. 16+8. Washington DC: USDA. Econ. Res. Service.

Rogers, P.J. and J.E. Blundell. 1991. Mechanisms of diet selection: the translation of needs into behavior. Proc. Nutr. Soc. 50:65-70.

Rolston, Holmes, III. 1989. Philosophy gone wild. Prometheus Books. Buffalo. New York, N.Y.

Romesburg, H. 1981. Wildlife Science: Gaining reliable knowledge. J. Wildl. Manage. 45:293-313.

Rose, A.F. 1991. An alternative to fences. Rangelands 13:144-145.

Sanford, S. 1983. Management of pastoral development in the third world. Wiley, Sommerset, N.J.

Senft, R.L., M.B. Coughenour, D.W. Bailey, L.R. Rittenhouse, O.E. Sala and D.M. Swift. 1987. Large herbivore foraging and ecological hierarchies. BioSci. 37:789-799.

Society for Range Management. 1989. A glossary of terms used in range management. Soc. Range Manage., Denver, Colo.

Stuth, J.W., J.R. Conner, W.T. Hamilton, D.A. Riegel, B.G. Lyons, B.R. Myrick and M.J. Couch. 1990. RSPM: a resource systems planning model for integrated resource management. J. Biogeo. 17:531-540.

Stuth, J.W., C.J. Scifres, W.T. Hamilton and J.R. Conner. 1991. Management systems analysis as guidance for effective interdisciplinary grazingland research. Agr. Sys. 36:-43-63.

Swasy, A. 1994. America's 20 hottest white-collar addresses. The Wall Street J. 129:B1, B3.

Taylor, C.A., Jr., Garza, N.E.,. Jr, Brooks, T. D. 1993. Grazing systems and the Edwards Plateau of Texas: Are they worth the trouble? II. Livestock response. Rangelands. 15: 57-60.

Taylor, C. A., Kothmann, M. M., Merrill, L. B., and Elledge, D. 1980. Diet selection by cattle under high-intensity low-frequency, short duration. and Merrill grazing systems. J. Range Manage. 33: 428-434.

Vallentine, J.F. 1990. Grazing management. Academic Pres, Inc., San Diego, Calif.

Volesky, J.D. 1990. Frontal grazing: forage harvesting of the future? Rangelands 12:177-181.

Wachenheim, D.E., L.L., Blythe, and A.M. Craig. 1992. Characterization of rumen bacterial pyrrolizidine alkaloid biotransformation in ruminants of various species. Vet. Hum. Toxicol. 34:513-517.

Waldrop, M.M. 1992. Complexity the emerging science at the edge of order and chaos. Simon and Schuster, New York. N.Y.

Walker, B.H. 1988. Autecology, synecology, climate and livestock as agents of rangeland dynamics. Aust. Rangel. J. 10:69-75.

Walker, B.H. 1993. Rangeland ecology: understanding and managing change. Ambio. 22:80-\$7.

Walker, J.W., R.K. Heitschmidt, and S.L. Dowhower. 1988a. Cattle preference for plant communities on rotational and continuous grazing treatments. J. Range Manage. 42:143-148.

Walker, J.W., R.K. Heitschmidt, E.A. de Moraes, M.M. Kothmann, and S.L. Dowhower. 1988b. Quality and botanical composition of cattle diets under rotational and continuous grazing treatments. J. Range Manage. 42:239-242.

Wallin, A. 1988. The genetics of foraging behavior: artificial selection for food choice in larvae of the fruitfly, Drosophila melanogaster. Anim. Behav. 36:106-114.

West, N.E., K. McDaniel, E.L. Smith, P.T. Tueller, and S. Leonard. Monitoring and interpreting ecological integrity on arid and semi-arid lands of the Western United States. New Mexico Range Improvement Task Force. Las Cruces. Rep. 37.

Westoby, M., B. Walker, and I. Noy-Meir. 1989. Opportunistic management for rangelands not at equilibrium. J. Range Manage. +2:266-274. 